\title{
SUMMER MEETING OF THE MEDICAL SOCIETY FOR THE STUDY OF VENEREAL DISEASES, 1928
}

ON Saturday, July I4th, I928, some thirty to forty members of the Society and their friends met in the Common Room of Queen's College, Oxford, for the purpose of discussing lunch as a prelude to the more sober business of the afternoon.

The fact that Sir Humphry Rolleston was unable to be present to contribute to the geniality of an otherwise merry assemblage was a source of disappointment to the members, who thus missed an opportunity of saying "Au Revoir" to the President who had so ably and ungrudgingly watched over and directed the fortunes of the Society during the last two years.

Dr. A. G. Gibson presided, and the members demonstrated in no dubious manner their appreciation of the fare which, by the thoughtful skill of the college chef, was so admirably correlated to the nature of the occasion and to the scorching thermal conditions of the day.

The Council wishes to record its appreciation of the kindness of the Master and Fellows of Queen's College in enabling the members of the Society to meet amidst such historical and picturesque surroundings.

The seventh annual general meeting was held (by kind permission of the Governors) at the Radcliffe Infirmary at 3 p.m.

The chair was taken by Colonel L. W. HARRISON, D.S.O. An epitome of the minutes of the last Annual General Meeting was read by the Hon. Secretary. The Chairman read the Report of the Hon. Treasurer. He referred to the work done by Dr. Menzies, through whose able efforts the financial condition of the Society has been so markedly improved. On his proposal a vote of thanks to Dr. Menzies was carried by acclamation. 


\section{BRITISH JOURNAL OF VENEREAL DISEASES}

The Chairman then gave an encouraging report as to the position of the BRITISH'JouRnal OF VENEREAL DISEASES.

Dr. Clarkson read the report of the Secretary and that of the Secretary of the Scottish Branch. Both statements were adopted without dissent.

The election of the officers for the coming year then took place with the following result :-

President.-Francis J. H. Coutts, C.B., M.D., D.P.H.

Past Presidents.-David Watson, M.B., C.M. ; L. W. Harrison, D.S.O., M.B., Ch.B., F.R.C.P. Ed., BrevetCol. R.A.M.C., K.H.P. (Ret.) ; Wilfrid S. Fox, M.D., F.R.C.P. ; Sir Humphry Rolleston, Bart., K.C.B., M.D., Regius Professor of Physic, Cambridge.

Vice-Presidents.-H. G. Adamson, M.D., F.R.C.P..; Sir Anthony A. Bowlby, Bart., K.C.B., K.C.M.G., K.C.V.O., F.R.C.S. ; E. T. Burke, D.S.O., M.B., Ch.B. ; Major A. T. Frost, O.B.E., M.B., B.Ch., R.A.M.C.; Sir Thomas J. Horder, Bart., K.C.V.O., M.D., F.R.C.P. ; Frank Kidd, M.Ch., F.R.C.S. ; David Lees, D.S.O., F.R.C.S. Ed. ; F. N. Kay Menzies, M.D., F.R.C.P. Ed., D.P.H., F.R.S.E. ; Morna Rawlins, M.B., B.S. ; James H. Sequeira, M.D., F.R.C.P., F.R.C.S. ; Sir John Thomson-Walker, O.B.E., M.B., C.M., F.R.C.S. ; Dennis Vinrace, M.R.C.S.

Members of the Council.-W. H. Brown, M.D., Ch:B. ; Robert Forgan, M.C., M.B., Ch.B.; H. M. Hanschell, D.S.C., M.R.C.S., L.R.C.P. ; Major-General D. Harvey, C.M.G., C.B.E., M.D., K.H.S. ; S. Hardy Kingston, M.B., Ch.B., D.P.H. ; V. E. Lloyd, M.C., M.B., B.S. ; Squad.Leader T. C. Morton, R.A.F.M.S., M.D., M.R.C.P.; D. N. Nabarro, M.D., F.R.C.P. ; Philip Panton, M.B., Ch.B. ; Margaret Rorke,..M.B., Ch.B. ; Frank Fowler Ward, M.B., B.Ch.

Hon. Treasurer-F. N. Kay Menzies, M.D., F.R.C.P Ed., D.P.H., F.R.S.E.

Hon. Secretary.-E. R. Townley Clarkson, M.R.C.S., L.R.C.P.

The CHAIRMAN said it was a great pleasure to him that Dr. Coutts had found it possible to become President of the Society, and he extended a cordial welcome to him on his assumption of that office. Dr. Coutts was in charge at the Ministry of Health of the administrative side of the work bearing upon venereal disease, and all who ran clinics owed him a debt of gratitude for the sym- 


\section{ANNUAL MEETING}

pathetic attitude he adopted towards the problems which arose in that connection. He was sure Dr. Coutts would be of enormous use to the Society during his occupancy of the chair.

The President said that it was with considerable misgivings that he consented to his name being put forward for the position of President, as he felt like a fish out of water coming among practical clinicians in this special branch, as his own clinical days were over many years ago. He assumed that the reason of his nomination was because it was felt by the members that venereal disease work had a close relation to public health activities, and that the treatment of patients afflicted with venereal diseases not only benefited those patients, but also increased the general health of the community.

The PRESIDENT proposed that a cordial vote of thanks be given to Colonel Harrison for having presided over the earlier part of the meeting and for consenting to do so later on, as he was obliged to leave Oxford within a short time.

This was carried unanimously.

Dr. A. G. Gibson, Physician and Hon. Assistant Pathologist at Radcliffe Infirmary and County Hospital, then read a paper on "Some Remarks on the more Remote Complications of Gonorrhœa." *

The PREsident said that he was sure that all those who were present would feel greatly indebted to Dr. Gibson for this paper, which was so lucid and so far-reaching in its inquiry. It must have taken a good deal of preparation, and on so hot an afternoon to present it so ably was no light task. Hęaring this paper made one feel that the manifestations of gonorrhœa might be almost as protean as those of syphilis, though he hoped they were not as frequent.

A vote of thanks was accorded to Dr. Gibson for his illuminating and stimulating paper.

The second part of the meeting was held in the Outpatient Department of the Radcliffe Infirmary, where Dr. Gibson, in conjunction with Dr. Isabella M. Little and Drs. J. W. Alden and Mallan, demonstrated a most instructive series of clinical cases. That these aroused a very keen interest among the members was indicated

* $T$ ' is paper, with its resultant discussion, was published in this Journal in Octol er, 1928. 


\section{BRITISH JOURNAL OF VENEREAL DISEASES}

by the large amount of time which was spent in the examination and discussion of the conditions presented by the patients.

The Council wishes to place on record its appreciation of the energy and time which Dr. Gibson devoted to making the seventh annual general meeting of the Society at Oxford a conspicuous success both from the scientific and social points of view, since practically all the arrangements for the luncheon, the meeting, etc., were carried out by him in a manner which was as ungrudging of time and labour as it was successful in its achievement. 